\title{
IDENTIFIKASI PERSEPSI MAHASISWA TENTANG SISTEM PEMBELAJARAN KETERAMPILAN MEDIK PEMASANGAN KATETER URIN DI FAKULTAS KEDOKTERAN UNIVERSITAS MATARAM
}

\author{
Achmad Mujahidin Irham ${ }^{1}$, Akhada Maulana ${ }^{2}$, Arif Zuhan ${ }^{3}$ \\ 1. Program Studi Pendidikan Dokter Fakultas Kedokteran Universitas Mataram \\ 2. Bagian Urologi dan Bedah Fakultas Kedokteran Universitas Mataram \\ 3. Bagian Bedah Fakultas Kedokteran Universitas Mataram \\ Email: mujahidin196@gmail.com, akhada_m@hotmail.com dan \\ zuhan.arif@yahoo.co.id
}

\begin{abstract}
Abstrak
Penguasaan mahasiswa dalam keterampilan medik merupakan aspek yang sangat penting yang akan menjembatani antara kompetensi klinis dan pengetahuan prosedural. Berdasarkan Standar Kompetensi Dokter Indonesia 2012, keterampilan pemasangan kateter urin memiliki kompetensi 4A yang artinya seorang lulusan dokter layanan primer harus mampu melakukan secara mandiri, dengan menguasai teori, indikasi, kontraindikasi, serta komplikasi yang dapat muncul. Persepsi mahasiswa tentang sistem pembelajaran dan lingkungan belajar akan menjadi landasan dalam memaksimalkan dan memvariasikan sistem maupun lingkungan pembelajaran. Pengetahuan dasar mahasiswa terkait suatu sistem pembelajaran akan memengaruhi persepsi dan bagaimana proses belajar mahasiswa untuk selanjutnya. Penelitian ini adalah penelitian deskriptif dengan desain penelitian cross sectional pada mahasiswa semester V dan VII Program Studi Pendidikan Dokter Fakultas Kedokteran Universitas Mataram. Teknik pengambilan sampel mengunakan teknik total sampling dan sampel diminta mengisi kuesioner tentang persepsi keterampilan medik pemasangan kateter urin. Dari 196 responden terdiri dari laki-laki (34,7\%) dan perempuan $(65,3 \%)$ dengan rentang usia 19-23 tahun. Persepsi baik mengenai keterampilan medik pemasangan infus dilihat dari persentase dari faktor motivasi (96,9 \%), instruktur (89,8\%-100\%), kesadaran diri (99\%-100\%), suasana belajar $(81,1 \%-96,9 \%)$, sarana dan prasarana $(43,4 \%-89,3 \%)$, kepercayaan diri $(57,7 \%$ $99,5 \%)$, dan lingkungan belajar klinik $(89,8 \%)$. Adapun persepsi tidak baik hanya terdapat pada perbedaan belajar di manekin dengan pasien $(56,6 \%)$. Mayoritas mahasiswa memiliki persepsi baik tentang sistem pembelajaran keterampilan medik pemasangan kateter urin.
\end{abstract}

Kata kunci: Persepsi Mahasiswa; Keterampilan Medik; Pemasangan Kateter Urin.

\begin{abstract}
Mastery of students in medical skills is a very important aspect that will bridge the gap between clinical competence and procedural knowledge. Based on the 2012 Indonesian Doctor Competency Standards, urinary catheter installation skills have $4 A$ competencies, which means that a primary care doctor graduate must be able to do it independently, by mastering theory, indications, contraindications, and complications that can arise. Students' perceptions of the learning system and learning environment will be the basis for maximizing and varying the learning system and environment. Basic knowledge of students related to a learning system
\end{abstract}


will affect the perception and how the student learning process in the future. This research is a descriptive study with a research design cross sectional for students in the fifth and seventh semesters of the Medical Education Study Program, Faculty of Medicine, University of Mataram. The sampling technique used a total sampling technique and the sample was asked to fill out a questionnaire about perceptions of medical skills in inserting a urinary catheter. From 196 respondents consisting of men (34.7\%) and women (65.3\%) with an age range of 19-23 years. Good perception of medical skills in infusion is seen from the percentage of motivation factors (96.9 $\%)$, instructors (89.8\%-100\%), self-awareness (99\%-100\%), learning atmosphere (81.1\%-96 .9\%), facilities and infrastructure (43.4\%-89.3\%), self-confidence (57.7\%-99.5\%), and clinical learning environment (89.8\%). The bad perception is only found in the difference between learning in the mannequin and the patient (56.6\%). The majority of students have a good perception of the medical skills learning system of urinary catheter insertion.

Keywords: Student Perception; Medical Skills; Urinary Catheter Insertion.

Diterima: 15-12-2021Ｄirevisi: 10-01-2022Ｄiterbitkan: 20-01-2022

\section{Pendahuluan}

Salah satu bagian dari instansi pendidikan yang menggunakan kegiatan keterampilan medik sebagai sarana pembelajaran keterampilan yang berbasis klinis adalah Fakultas Kedokteran Universitas Mataram. Dari berbagai jenis keterampilan medis yang diajarkan, salah satunya yaitu keterampilan medik berupa teknik pemasangan kateter urin, yang didapatkan mahasiswa Fakultas Kedokteran Universitas Mataram pada semester V pada mahasiswa angkatan 2019 dan pada semester II pada mahasiswa angkatan 2018.

Berdasarkan Standar Kompetensi Dokter Indonesia tahun 2012, keterampilan medik pemasangan kateter urin memiliki kompetensi 4A yang artinya seorang lulusan dokter layanan primer harus mampu melakukan secara mandiri. Selain itu dokter juga harus menguasai seluruh teori, prinsip, indikasi, kontraindikasi, hingga komplikasi yang dapat ditimbulkan dari keterampilan medik tersebut (KKI, 2012).

Aspek persepsi dalam kegiatan pembelajaran saat ini mulai banyak mendapatkan perhatian dengan tujuan mengevaluasi kegiatan pembelajaran. Persepsi mahasiswa tentang sistem pembelajaran dan lingkungan belajar akan menjadi landasan dalam memaksimalkan dan memvariasikan sistem maupun lingkungan pembelajaran (Hongkan et al., 2018). Pengetahuan dasar mahasiswa terkait suatu sistem pembelajaran akan memengaruhi persepsi dan bagaimana proses belajar serta nilai kepuasan mahasiswa untuk selanjutnya (Arfi \& Ansyori, 2012; Saputra, Widyandana, \& Hadianto, 2014).

Persepsi mahasiswa memiliki hubungan dengan capaian belajar yang diperoleh mahasiswa. Menurut penelitian yang dilakukan Ahmed et al, menyebutkan bahwa, mahasiswa yang memiliki capaian belajar yang lebih tinggi menunjukkan persepsi lebih positif terhadap kegiatan pembelajaran mereka, sementara mahasiswa yang memiliki capaian belajar yang rendah menunjukan persepsi yang negatif terhadap kegiatan pembelajaran mereka (Ahmed, Taha, Al-Neel, \& Gaffar, 2018). Persepsi positif 
mahasiswa tentang kegiatan pembelajaran merupakan gambaran keberhasilan dari suatu kegiatan pembelajaran. Penelitian tentang persepsi mahasiswa kedokteran terhadap pembelajaran keterampilan medik pernah dilakukan Shuid et al., di Universitas Kebangsaan Malaysia. Hasil dari penelitian tersebut menunjukkan mahasiswa memiliki persepsi positif terhadap pembelajaran keterampilan medik yang telah diajarkan, hal tersebut dipengaruhi oleh modul pembelajaran keterampilan medik pada universitas tersebut dengan persentase sebesar 70,8 \% (Shuid et al., 2015).

Penguasaan terhadap keterampilan medik merupakan aspek yang sangat penting yang menjembatani antara pengetahuan prosedural dan kompetensi klinis. Pembelajaran keterampilan medik membantu memastikan semua mahasiswa memperoleh penguasaan teknik yang diperlukan dan dinilai benar sebelum diaplikasikan langsung pada pasien sesungguhnya (Imran, Ramzan, Nadeem, Khan, \& Tariq, 2019).

Studi pendahuluan juga didapatkan dari bagian keterampilan medik Fakultas Kedokteran Universitas Mataram yang menyatakan bahwa data jumlah mahasiswa yang lulus pada ujian keterampilan medik pemasangan kateter urin mengalami penurunan jumlah dari tahun ketahun.

Dari beberapa permasalahan tersebut, peneliti ingin melakukan penelitian di Fakultas Kedokteran Universitas Mataram untuk mengevaluasi sistem pembelajaran keterampilan medik teknik pemasangan kateter urin, selain itu juga masih minimnya serta belum ada penelitian yang mengevaluasi persepsi mahasiswa tentang sistem pembelajaran keterampilan medik pemasangan kateter urin, sehingga perlu dilakukan untuk melihat persepsi mahasiswa terhadap sistem pembelajaran keterampilan medik pemasangan kateter urin. Hasil dari penelitian ini dapat digunakan sebagai informasi awal untuk meningkatkan keefektifan sistem pembelajaran keterampilan medik pemasangan kateter urin untuk tahun berikutnya.

\section{Metode Penelitian}

Metode penelitian yang digunakan dalam penelitian ini adalah penelitian deskriptif dengan rancangan desain penelitian potong lintang (cross-sectional) yang menjabarkan persepsi tentang sistem pembelajaran keterampilan medik pemasangan kateter urin. Penilaian dilakukan menggunakan kuisioner kepada mahasiswa semester V dan VII yang telah mengikuti pembelajaran keterampilan tersebut.

Penelitian ini akan dilaksanakan di Fakultas Kedokteran Universitas Mataram. Waktu pelaksanaan penelitian mulai dari bulan Juli sampai dengan Agustus 2021. Jumlah responden sebanyak 196 mahasiswa. Alat yang digunakan untuk penilaian persepsi mahasiswa tentang sistem pembelajaran keterampilan medik pemasangan kateter urin pada penelitian ini adalah kuisioner yang dibuat oleh Hashim et al., namun sudah dimodifikasi oleh peneliti, kuisioner yang digunakan sudah teruji validitas dan realibilitasnya. Kuisioner terdiri dari 26 pernyataan, dimana reponden harus mengisi salah satu pilihan berupa Sangat tidak setuju, Tidak setuju, Setuju, dan Sangat Setuju dari masing-masing pernyataan. 
Data-data yang sudah terkumpul akan dimasukkan dan diolah ke dalam tabel dengan menggunakan Microsoft Excel dan aplikasi Statistical Product and Service Solution (SPSS) untuk memperoleh hasil statistik yang diharapkan. Selanjutnya data akan dianalisis secara deskriptif dan hasilnya berupa presentase dan frekuensi (Dahlan, 2013). Data akan disajikan dalam bentuk narasi, tabel dan grafik. Proses terakhir adalah penyusunan laporan.

\section{Hasil}

Pada penelitian ini terdapat 196 mahasiswa yang berpartisipasi. Terdiri dari 68 laki laki dan 128 perempuan. Rentang usia responden adalah 19-23 tahun, dilakukan untuk menilai persepsi mahasiswa tentang sistem pembelajaran keterampilan medik pemasangan kateter urin di Fakultas Kedokteran Universitas Mataram dengan mengunakan kuesioner. Pengambilan data mengunakan kuesioner dilakukan pada bulan September 2021. Responden pada penelitian ini merupakan mahasiswa Program Studi Pendidikan Dokter Fakultas Kedokteran semester V dan semester VII yang memenuhi kriteria inklusi dan eksklusi. Karakteristik responden pada penelitian ini meliputi jenis kelamin dan usia.

Tabel 1. Karateristik Responden

\begin{tabular}{lll}
\hline $\begin{array}{l}\text { Jenis } \\
\text { kelamin }\end{array}$ & $\mathbf{N}$ & $\mathbf{\%}$ \\
\hline Laki-laki & 68 & 34,7 \\
\hline Perempuan & 128 & 65,3 \\
\hline Usia & & \\
\hline 19 tahun & 11 & 5,6 \\
\hline 20 tahun & 78 & 39,8 \\
\hline 21 tahun & 93 & 47,4 \\
\hline 22 tahun & 11 & 5,6 \\
\hline 23 tahun & 3 & 1,5 \\
\hline Total & 196 & 100 \\
\hline
\end{tabular}

Pada Tabel 1 ditampilkan jumlah responden laki-laki berjumlah 68 mahasiswa $(34,7 \%)$ dan responden perempuan 128 mahasiswa (65,3\%). Selain itu ditampilkan jumlah responden yang berusia 19 tahun sebanyak 11 (5,6 \%), responden berusia 20 tahun sebanyak $78(39,8 \%)$, responden berusia 21 tahun sebanyak $93(47,4 \%)$, responden berusia 22 tahun sebanyak $11(5,6 \%)$ responden berusia 23 tahun sebanyak $3(1,5 \%)$. 
Identifikasi Persepsi Mahasiswa Tentang Sistem Pembelajaran Keterampilan Medik Pemasangan Kateter Urin Di Fakultas Kedokteran Universitas Mataram



\section{Gambar 1 Grafik persepsi responden}

Pada faktor motivasi terdiri dari 2 butir pernyataan. Pada pernyataan nomor 1 tentang pelatihan keterampilan medik pemasangan kateter urin memotivasi menjadi dokter, responden memiliki persepsi baik 96,9\% dan persepsi tidak baik 3,1\%. Pada pernyataan nomor 2 tentang pelatihan keterampilan medik pemasangan kateter urin memotivasi untuk mempelajari mata kuliah klinis, responden berpersepsi baik 96,9\% dan persepsi tidak baik $3,1 \%$. 
Pada faktor instruktur terdiri dari 6 butir pernyataan pada nomor 3 sampai 8. Pada pernyataan nomor 3 tentang instruktur berkomitmen dalam mengajar, seluruh responden memiliki persepsi baik. Pada pernyataan nomor 4 tentang instruktur datang tepat waktu, responden memiliki persepsi baik $89,8 \%$ dan persepsi tidak baik 10,2\%. Pada pernyataan nomor 5 tentang instruktur mengajar keterampilan sesuai modul, seluruh responden memiliki persepsi baik. Pada pernyataan nomor 6 tentang instruktur mendemostrasikan keterampilan medik pemasangan kateter urin hingga mahasiswa mengerti apa yang harus saya lakukan, seluruh responden memiliki persepsi baik. Pada pernyataan 7 tentang instruktur mendemonstrasikan keterampilan medik pemasangan kateter urin sebelum saya melakukan, responden memiliki persepsi baik 99,5\% dan persepsi tidak baik 0,5\%. Pada pernyataan nomor 8 tentang instruktur memberi tahu apa yang harus dipelajari, seluruh responden memiliki persepsi baik.

Pada faktor kesadaran diri terdiri dari 4 butir pada pernyataan nomor 9 sampai 12 . Pada pernyataan nomor 9 tentang responden harus berpartisipasi aktif di kelas keterampilan medik, seluruh responden berpersepsi baik baik. Pada pernyataan nomor 10 tentang mahasiswa mengikuti semua pelatihan yang ada di keterampilan medik pemasangan kateter urin, seluruh responden berpersepsi baik. Pada pernyataan nomor 11 tentang mahasiswa mengembangkan pendekatan profesionalitas etika di kelas keterampilan medik, responden berpersepsi baik $99 \%$ dan berpersepsi tidak baik $1 \%$. Pada pernyataan nomor 12 tentang pelatihan keterampilan medik pemasangan kateter urin bermaanfaat, seluruh responden berpersepsi baik.

Pada faktor suasana belajar terdiri 4 butir pernyataan pada pernyataan nomor 13 sampai 16. Pada pernyataan nomor 13 tentang suasana di kelas tidak terlalu ramai, responden berpersepsi baik $81,1 \%$ dan berpersepsi tidak baik $18,9 \%$. Pada pernyataan nomor 14 tentang responden tidak tertekan selama pelatihan, responden berpersepsi baik 92,8\% dan berpersepsi tidak baik sebanyak 7,2\%. Pada pernyataan nomor 15 tentang pelatihan di kelas keterampilan medik pemasangan kateter urin telah meningkatkan hasil belajar mandiri, responden berpersepsi baik 96,9\% dan berpresepsi tidak baik 3,1\%. Pada pernyataan nomor 16 tentang jarak waktu pemebelajaran dengan fase klinik sudah tepat, responden berpresepsi baik 86,7\% dan berpresepsi tidak baik sebesar 13,3\% .

Pada faktor sarana dan prasarana terdiri dari 4 butir pernyataan pada nomor 17 sampai 20. Pada pernyataan nomor 17 tentang keterampilan medik pemasangan kateter urin yang dipelajari dengan manekin dapat diaplikasikan langsung pada pasien, responden berpersepsi baik $81,6 \%$ dan berpersepsi tidak baik 18,4\%. Pada pernyataan nomor 18 tentang terdapat perbedaan antara belajar keterampilan medik pemasangan kateter urin pada manekin dengan pasien, responden berpersepsi baik 43,4\% dan berpersepsi tidak baik 56,6\%. Pada pernyataan nomor 19 tentang kualitas manekin kateter urin pada laboratorium keterampilan medik baik, responden berpersepsi baik 83,2\% dan berpersepsi tidak baik 16,8\%. Pada pernyataan nomor 20 tentang jumlah manekin kateter urin pada laboratorium keterampilan medik cukup, responden berpersepsi baik 89,3\% dan berpersepsi tidak baik $10,7 \%$. 
Pada faktor kepercayaan diri terdiri dari 5 butir pada pernyataan nomor 21 sampai 25. Pada pernyataan nomor 21 tentang percaya diri adalah hal yang penting ketika mereka melakukan keterampilan medis pemasangan kateter urin, responden berpersepsi baik 99,5\% dan berpersepsi tidak baik 0,5\%. Pada pernyataan nomor 22 tentang pelatihan keterampilan medik pemasangan kateter urin menambah kepercayaan diri mereka, responden berpersepsi baik 95,9\% dan berpersepsi tidak baik 4,1\%. Pada pernyataan nomor 23 tentang tidak perlu takut bahwa mereka akan melukai pasien, responden berpersepsi baik 57,7\% dan berpersepsi tidak baik 42,3\%. Pada pernyataan nomor 24 tentang merasa tidak takut jika mereka melakukan kesalahan selama pelatihan keterampilan medik pemasangan kateter urin, responden berpersepsi baik 94,9\% dan berpersepsi tidak baik $5,1 \%$. Pada pernyataan tentang saat ujian mereka merasa percaya diri dan menguasai keterampilan medik pemasangan kateter urin, responden berpresepsi baik 93,3\% dan berpresepsi tidak baik 6,7\%.

Pada faktor lingkungan belajar klinik terdiri dari 1 butir pernyataan pada nomor 26. Pada pernyataan nomor 26 tentang belajar kepaniteraan klinik memberikan peluang yang lebih baik untuk mempelajari keterampilan medik, responden berpersepsi baik $89,8 \%$ dan berpersepsi tidak baik $10,2 \%$.

\section{Pembahasan}

Hasil dari penelitian ini menunjukan bahwa persepsi mahasiswa tentang pembelajaran keterampilan medik pemasangan kateter urin dapat dilihat dari beberapa faktor. Faktor tersebut berupa motivasi, instruktur, kesadaran diri, suasana belajar, sarana dan prasarana, kepercayaan diri, dan lingkungan belajar kepaniteraan klinik.

Motivasi memiliki hubungan dengan kepribadian dan sikap positif mahasiswa dalam hal ketekunan, kecerdasan sosial, kedisplinan dan rasa syukur (Kunanitthaworn et al., 2018). Berdasarkan penelitian ini, mayoritas responden berpendapat bahwa keterampilan medik meningkatkan motivasi menjadi dokter dan motivasi mempelajari pelajaran klinis lainnya. Hal ini sejalan dengan penelitian sebelumnya yang dilakukan oleh Hashim et al., yang dilakukan pada 137 responden (Hashim, Qamar, Khan, \& Rehman, 2016). Motivasi yang kuat dalam proses pembelajaran seorang mahasiswa kedokteran sangat dibutuhkan demi keberhasilan akademik dan peningkatan profesionalisme diri (Kunanitthaworn et al., 2018).

Kemampuan instruktur dalam mengajar memengaruhi persepsi mahasiswa terhadap pembelajaran keterampilan medik. Pada penelitian ini mayoritas responden berpendapat baik terhadap kemampuan instruktur. Kemampuan ini meliputi kemampuan mendemonstrasikan prosedur keterampilan medik dengan benar dan komitmen dalam mengajar penuh tanggung jawab, sehingga responden merasa mendapatkan gambaran dengan baik dan mampu melakukan prosedur yang telah dicontohkan. Pada penelitian yang dilakukan oleh Erikson menunjukkan bahwa semakin baik kemampuan instruktur dalam mengajar, maka persepsi responden terhadap keterampilan medik juga semakin baik. Kemampuan mengajar instruktur yang baik mempercepat penyerapan materi dalam waktu yang lebih singkat sehingga persepsi responden akan lebih baik dan responden 
akan lebih merasakan manfaat dari pembelajaran keterampilan medik (Erickson \& Kristina, 2012).

Pada penelitian ini responden memiliki kesadaran diri yang baik seperti mengikuti semua keterampilan medik, bersikap professional, berpartisipasi aktif dan menggangap keterampilan medik bermanfaat untuk responden. Adapun penelitian yang dilakukan oleh Flavian bahwa kesadaran diri yang stabil akan sangat bermanfaat dalam kemajuan dan proses pembelajaran mahasiswa terhadap berbagai aspek dalam kehidupan. Kesadaran diri yang baik berpengaruh terhadap peningkatan prestasi akademik mahasiswa (Flavian, 2016).

Suasana belajar menggambarkan kualitas pembelajaran dan memengaruhi hasil belajar mahasiswa. Suasana belajar yang kondusif ditandai dengan interaksi instruktur dan mahasiswa yang nyaman sehingga meningkatkan antusias dan percaya diri mahasiswa dalam mengikuti pelajaran (Rahmawaty, 2018). Pada penelitian suasana belajar yang nyaman terbentuk dari interaksi yang baik antara responden dengan teman satu kelompok keterampilan medik dan instrukturnya. Hal ini sejalan dengan penelitian sebelumnya yang dilakukan oleh Saputra dan Lisiswati bahwa suasana belajar yang kondusif akan tercipta dari sikap dan cara instrukur menyampaikan materi, interaksi antara teman satu kelompok keterampilan medik dan antusias satu kelompok keterampilan medik dalam belajar keterampilan tersebut (Saputra \& Lisiswanti, 2015).

Pada penelitian ini responden berpendapat bahwa prosedur yang dipelajari pada manekin dapat diaplikasikan langsung pada pasien. Hal ini sejalan dengan penelitian yang dilakukan oleh Erikson bahwa sarana dan prasana keterampilan medik memengaruhi persepsi terhadap keterampilan medik. Semakin baik sarana dan prasarana yang disediakan, baik disini diartikan sebagai baik dalam hal kualitas maupun kuantitas dari manekin itu sendiri, maka akan semakin maksimal manfaat pelatihan keterampilan medik yang diperoleh mahasiswa (Erickson \& Kristina, 2012). Namun pada penelitian ini responden juga berpendapat terdapat perbedaan antara belajar keterampilan medik pada manekin dengan pasien yang sesungguhnya. Penelitian ini sejalan dengan penelitian sebelumnya yang dilakukan oleh Lavanya dan Kalpana, bahwa manekin harus lebih realistis. Selain itu, kulit manekin berbeda dengan kulit manusia, bahkan tidak dapat diketahui apakah ada perforasi atau emboli (Lavanya \& Kalpana, 2018).

Mahasiswa yang lebih percaya diri terhadap kemampuannya mengaplikasikan lebih banyak pengetahuan, keterampilan dan kecakapan dalam melakukan tantangan baru terkait cara merawat pasien (Bond \& Cone, 2012). Pada penelitian ini responden berpendapat kepercayaan diri merupakan hal penting dalam pembelajaran keterampilan medik yaitu untuk meningkatkan kepercayaan diri responden. Hal ini sejalan dengan penelitian yang dilakukan oleh Erikson bahwa tingkat kepercayaan diri memengaruhi persepsi terhadap keterampilan medik, dimana responden dengan kepercayaan diri yang tinggi akan merasa keterampilan medik memiliki manfaat untuknya dan sebaliknya (Erickson \& Kristina, 2012).

Pada penelitian ini responden berpendapat bahwa lingkungan belajar kepaniteraan klinik memberikan peluang yang lebih baik untuk mempelajari keterampilan medik. Hal 
ini sejalan dengan penelitian sebelumnya yang dilakukan oleh Nielsen at al. mengemukaan bahwa belajar keterampilan di kepaniteraan klinik memberi kesempatan yang lebih baik kepada mahasiswa bila dibandingkan dengan di laboratorium keterampilan medik (Nielsen, Moercke, Wickmann-Hansen, \& Eika, 2003). Namun pada penelitian ini responden juga berpendapat bahwa pembelajaran keterampilan medik tidak cukup apabila hanya di lakukan ketika di kepaniteraan klinik. Hal ini sejalan dengan penelitian sebelumnya oleh Sandika bahwa pembelajaran keterampilan medik dibutuhkan di semua jenjang pendidikan sehingga mempermudahkan mahasiswa menguasai keterampilan medik (Sandika, 2012).

\section{Kesimpulan}

Responden memiliki persepsi baik untuk komponen pernyataan seperti faktor motivasi, instruktur, kesadaran diri, suasana belajar, sarana dan prasarana, kepercayaan diri dan lingkungan belajar klinik. Adapun persepsi tidak baik yaitu hanya terdapat pada perbedaan belajar di manekin dengan pasien.

Saran dari penelitian ini, untuk departemen keterampilan medik Fakultas Kedokteran Universitas Mataram perlu meningkatkan kualitas dari sarana dan prasarana untuk menunjang kemampuan mahasiswa. Adapun untuk meningkatkan kepercayaan diri mahasiswa pada pembelajaran keterampilan medik pemasangan kateter urin perlu diadakan program khusus seperti training motivasi pengembangan kepercayaan diri mahasiswa sebelum memulai keterampilan medik tersebut. 


\section{BIBLIOGRAFI}

Ahmed, Yasar, Taha, Mohamed H., Al-Neel, Salma, \& Gaffar, Abdelrahim M. (2018). Students' perception of the learning environment and its relation to their study year and performance in Sudan. International Journal of Medical Education, 9, 145-150. https://doi.org/10.5116/ijme.5af0.1fee Google Scholar

Arfi, Syamsun, \& Ansyori, Mas Isa. (2012). Standarisasi Pasien dan Ruang Simulasi meningkatkan Kepuasan Mahasiswa Kedokteran Universitas Mataram dalam Pelaksanaan Keterampilan Medik Kardiovaskuler. Jurnal Kedokteran Universitas Mataram, 1, 68-73. Google Scholar

Bond, Rucha, \& Cone, Catherine. (2012). Improving student confidence in skill performance in a pharmaceutical care lab setting. Pharmacy Education, 12(1), 2024. Google Scholar

Dahlan, M. Sopiyudin. (2013). Besar Sampel dan Cara Pengambilan Sampel (kettiga; Aklia Suslia, ed.). Jakarta: Salemba Medika. Google Scholar

Erickson, Rayno Praditya, \& Kristina, Tri Nur. (2012). Persepsi Mahasiswa Kepaniteraan Klinik Terhadap Pelatihan Keterampilan Klinik di Akhir Pendidikan Sarjana Kedokteran. Jurnal Kedokteran Diponegoro, 1(1), 1-16. Google Scholar

Flavian, Heidi. (2016). Towards teaching and beyond: Strengthening education by understanding students' self-awareness development. Power and Education, 8(1), 88-100. https://doi.org/10.1177/1757743815624118 Google Scholar

Hashim, Rizwan, Qamar, Khadija, Khan, Muhammad Alamgir, \& Rehman, Sabah. (2016). Role of skill laboratory training in medical education - Students' perspective. Journal of the College of Physicians and Surgeons Pakistan, 26(3), 195-198. https://doi.org/03.2016/JCPSP.195198 Google Scholar

Imran, Shezadi Sabah, Ramzan, Musarat, Nadeem, Sadia, Khan, Oswha, \& Tariq, Sadia. (2019). Effect of skill laboratory training on academic performance of medical students. Rawal Medical Journal, 44(4), 844-847. Google Scholar

KKI. (2012). Peraturan KKI No.11 Tentang Standar Kompetensi Dokter Indonesia. Google Scholar

Kunanitthaworn, Natchaya, Wongpakaran, Tinakon, Wongpakaran, Nahathai, Paiboonsithiwong, Salilthip, Songtrijuck, Natchaphon, Kuntawong, Pimolpun, \& Wedding, Danny. (2018). Factors associated with motivation in medical education: A path analysis. BMC Medical Education, 18(1), 1-9. https://doi.org/10.1186/s12909-018-1256-5 Google Scholar

Lavanya, \& Kalpana. (2018). Mannequin-based simulation as an educational tool for learning injection techniques: medical students' view points. International Journal of Basic \& Clinical Pharmacology, 7(5), 882. https://doi.org/10.18203/23192003.ijbcp20181629 Google Scholar

Nielsen, Dorte Guldbrand, Moercke, Anne Mette, Wickmann-Hansen, Gitte, \& Eika, Berit. (2003). Skills Training in Laboratory and Clerkship: Connections, Similarities, and Differences. Medical Education Online, 8(1), 4334. 
Identifikasi Persepsi Mahasiswa Tentang Sistem Pembelajaran Keterampilan Medik Pemasangan Kateter Urin Di Fakultas Kedokteran Universitas Mataram

https://doi.org/10.3402/meo.v8i.4334 Google Scholar

Rahmawaty, Setyaningrum. (2018). How to improve classroom atmosphere and undergraduate nutrition students' performance in learning nutrition care process? International Journal of Learning, Teaching and Educational Research, 17(11), 154-174. https://doi.org/10.26803/ijlter.17.11.10 Google Scholar

Sandika, E. (2012). Identifikasi Kebutuhan Mahasiswa Kedokteran Terhadap Pelatihan Keterampilan Klinik Di Setiap Jenjang Pendidikan Sarjana. Jurnal Kedokteran Diponegoro, 1(1), 114200. Google Scholar

Saputra, Oktadoni, \& Lisiswanti, Rika. (2015). Faktor-faktor yang mempengaruhi keberhasilan pembelajaran keterampilan klinik di Institusi Pendidikan Kedokteran. Jurnal Kedokteran, 5(9), 104-109. https://doi.org/10.1063/1.4885046 Google Scholar

Saputra, Oktadoni, Widyandana, \& Hadianto, Tridjoko. (2014). Persepsi Terhadap Training From Senior Student Dalam Penguasaan Keterampilan Klinik. Jurnal Pendidikan Kedokteran Indonesia, 3(2), 108-119. Google Scholar

Shuid, Ahmad N., Yaman, Mohamad N., Abd Kadir, Rabiatul A., Hussain, Rizuana I., Othman, Siti N., Nawi, Azmawati M., Ugusman, Azizah, Daud, Faiz, Manap, Roslina A., \& Mohamed, Isa N. (2015). Effect of early clinical skills teaching on 3rd year medical students' learning: The student perspective. Journal of Taibah University Medical Sciences, 10(1), 26-32. Google Scholar

First publication right:

Jurnal Syntax Fusion: Jurnal Nasional Indonesia

This article is licensed under:

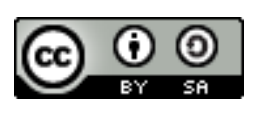

